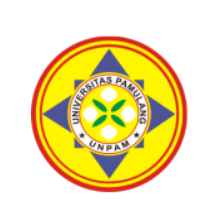
PERYUSS

\title{
DETERMINAN KEPUTUSAN HEDGING PADA PERUSAHAAN MANUFAKTUR YANG TERDAFTAR DI BURSA EFEK INDONESIA
}

\author{
${ }^{1 *}$ Tri Sulistyani, ${ }^{2}$ Diana Azwina \\ Universitas Pamulang, Tangerang Selatan, Banten, Indonesia \\ trisulistyani793@gmail.com
}

\begin{abstract}
Abstrak
Penelitian ini bertujuan untuk menganalisis pengaruh Leverage yang diproksikan dengan Debt To Equity Ratio (DER), Firm Size yang diproksikan dengan Total Asset dan Financial Distress yang diproksikan dengan metode Altman Z-Score terhadap Keputusan Hedging pada perusahaan manufaktur yang terdaftar di BEI periode 2017 - 2019. Populasi dalam penelitian ini adalah seluruh perusahaan manufaktur yang terdaftar di BEI pada tahun 2017-2019. Sampel pada penelitian ini berjumlah 26 perusahaan dengan menggunakan metode purpose sampling. Metode analisis yang digunakan dalam penelitian ini adalah metode regresi logistik untuk mengetahui variabel yang mempengaruhi penggunaan instrumen derivatif sebagai aktivitas lindung nilai. Hasil penelitian ini menunjukkan bahwa leverage yang diproksikan dengan DER memiliki arah koefisien regresi yang negatif dengan nilai signifikansi $0.431>0.05$, artinya leverage tidak berpengaruh signifikan terhadap keputusan hedging. Firm Size yang diproksikan dengan Total Aset memiliki arah koefisien regresi yang negatif, dengan nilai signifikansinya adalah 0,01 < 0,05 artinya total asset berpengaruh signifikan terhadap keputusan hedging dan Financial Distress yang diproksikan dengan metode Altman Z-Score memiliki arah koefisien regresi yang positif dengan nilai signifikansi $0.766>0.05$, artinya Financial Distress tidak berpengaruh signifikan terhadap keputusan hedging. Nilai Nagelkerke's $R$ Square sebesar 0,209 yang berarti variabel Leverage, Firm Size dan Financial Distress mampu menjelaskan variabel keputusan hedging pada Perusahaan Manufaktur sebesar 20,9\% dan sisanya sebesar 79.1\% dijelaskan oleh variabel lain di luar penelitian ini.
\end{abstract}

Kata Kunci: Leverage, Firm Size, Financial Distress dan hedging

\section{Abstract}

This study aims to analyze the effect of Leverage proxied by Debt To Equity Ratio (DER), Firm Size proxied by Total Assets and Financial Distress proxied by the Altman Z-Score method on Hedging Decisions in manufacturing companies listed on the IDX for the period 2017 - 2019. The population in this study were all manufacturing companies listed on the Indonesia Stock Exchange in 2017-2019. The sample in this study amounted to 26 companies using the purpose sampling method. The analytical method used in this study is the logistic regression method to determine the variables that affect the use of derivative instruments as hedging activities. The results of this study indicate that leverage proxied by DER has a negative regression coefficient direction with a significance value of $0.431>0.05$, meaning that leverage has no significant effect on hedging decisions. Firm Size proxied by Total Assets has a negative regression coefficient direction, with a significance value of $0.01<0.05$, meaning that total assets have a significant effect on hedging decisions and Financial Distress proxied by the Altman Z-Score method has a positive regression coefficient direction with a significance value of $0.766>0.05$, meaning that Financial Distress has no significant effect on hedging decisions. The value of Nagelkerke's R Square is 0.209, which means that the variables Leverage, Firm Size and Financial Distress are able to explain the hedging decision variables in Manufacturing Companies by $20.9 \%$ and the remaining $79.1 \%$ is explained by other variables outside of this study.

Keywords: Leverage, Firm Size, Financial Distress and hedging

\section{PENDAHULUAN}

Dalam kehidupan ini tiap negeri tentu memerlukan serta berhubungan dengan negeri lain, salah satunya ialah dengan melaksanakan perdagangan antar negeri ataupun yang biasa disebut perdagangan Internasional. Bagi Christianto (2013) Penafsiran perdagangan 
internasional secara simpel menurut kamus ekonomi ialah perdagangan yang terjalin antara 2 negeri ataupun lebih. Perdagangan luar negara ialah aspek berarti untuk perekonomian suatu negeri. Perdagangan internasional jadi terus menjadi berarti tidak cuma dalam pembangunan negeri yang berorientasi keluar akan tetapi juga dalam mencari pasar di negeri lain untuk hasil- hasil penciptaan di dalam negara dan pengadaan beberapa barang modal guna menunjang pertumbuhan industri di dalam negara. Perdagangan internasional dimulai dengan pertukaran ataupun perdagangan tenaga kerja dengan benda serta jasa yang lain. Bawah dalam perdagangan internasional merupakan terdapatnya perdagangan benda serta jasa antara 2 negeri ataupun lebih yang bertujuan buat memperoleh keuntungan. Perdagangan ini terjalin apabila ada permintaan serta penawaran pada pasar internasional.

Perdagangan Internasional pastinya pula mempunyai kesusahan serta kerumitan. Sebagian antara lain semacam permasalahan bahasa, kebijakan hukum dalam perdagangan, batas daerah serta perbandingan mata uang. Perihal tersebut pastinya hendak menghasilkan risiko yang bila tidak diolah dengan baik hendak memunculkan kerugian untuk negeri ataupun industri yang ikut serta didalamnya. Manajemen serta aksi yang pas sangat dibutuhkan agar bebas dari risiko- risiko tersebut. Resiko yang sangat kerap dirasakan oleh pelaku perdagangan internasional dalam transaksinya merupakan fluktuasi nilai ubah serta tingkatan suku bunga. Terdapat banyak metode yang dapat dicoba industri supaya bebas dari resiko tersebut serta salah satunya ialah dengan melaksanakan kegiatan lindung nilai (hedging). Keputusan dikerjakannya kebijakan hedging bisa dipengaruhi oleh aspek eksternal serta aspek internal. Aspek internal industri selaku variabel penjelas yang diidentifikasi mempengaruhi variabel pemakaian kebijakan hedging dalam riset ini ialah Leverage, Ukuran Perusahaan serta financial distress.

Risiko yang dialami oleh industri dalam transaksinya bisa ditimbulkan oleh faktor- faktor eksternal semacam fluktuasi tingkatan suku bunga, kurs valuta asing ataupun harga komoditas yang berakibat negatif terhadap arus kas, nilai industri dan mengecam kelangsungan hidup industri( Putro, 2012). Keadaan fluktuasi nilai tukar tukar Rupiah terhadap mata uang lain spesialnya dari sisi hard currencies bisa dilihat di Indonesia dalam sebagian tahun terakhir. Berikut nilai tukar Dollar Amerika terhadap Rupiah:

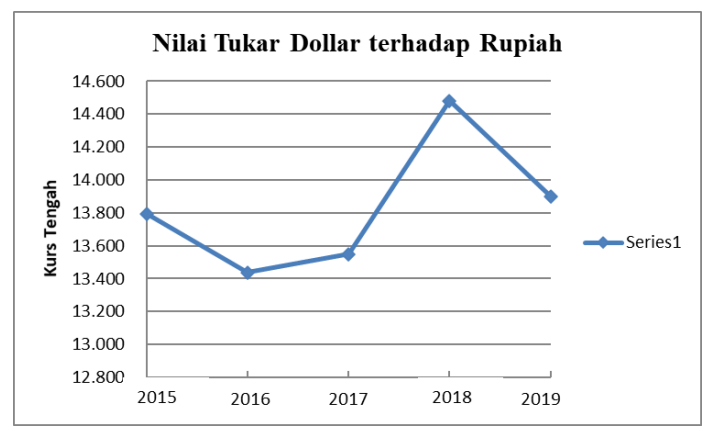

https://www.bps.go.id/linkTableDinami s/view/id/952

Berdasarkan Badan Pusat Statistik Nilai tukar Rupiah per Dollar Amerika pada tahun 2015 adalah Rp.13.795, kemudian pada tahun 2016 nilai tukar Rupiah Per Dollar Amerika cenderung menurun dengan nilai Rp.13.436, tahun 2017 nilai tukarnya adalah Rp.13.548 mengalami kenaikan sebesar Rp.112 dan pada tahun 2018 melonjak tinggi sebesar Rp.14.481 dan kemudian pada tahun 2019 mengalami penurunan sebesar Rp.580 dengan nilai tukar Rp.13.901.

Keadaan fluktuasi nilai tukar ini bisa berpengaruh terhadap nilai arus kas industri. Nilai arus kas yang diterima industri dalam bermacam satuan mata uang bisa terkena dampak kurs tiap- tiap mata uang tersebut saat dikonversi jadi mata uang dalam negeri, begitu pula dengan nilai kas keluar industri yang bergantung pada nilai tiap- tiap mata uang. Salah satu metode yang bisa diambil dalam menghadapi risiko tersebut dengan melaksanakan lindung nilai (hedging). Bagi 
Hanafi (2012) hedging ataupun lindung nilai pada dasarnya mentransfer risiko kepada pihak lain yang dapat mengelola risiko lebih baik lewat instrumen keuangan. Kegiatan hedging bisa dicoba dengan memanfaatkan instrumen derivatif. Bagi Hanafi (2012) instrumen derivatif merupakan instrumen yang nilainya diturunkan dari nilai aset yang menjadi dasarnya (underlying asset).

Tidak bisa dipungkiri jika industri yang melaksanakan perdagangan internasional hendak mempunyai utang ataupun piutang dalam wujud mata uang asing, sehingga fluktuasi valuta asing sangat mempengaruhi jumlah keuntungan yang hendak diterima. Meramal valuta asing ialah strategi yang sangat berarti untuk usaha bisnis internasional. Hanya apabila industri bisa meramal arah pergerakan kurs valuta asing, hingga industri bisa memutuskan dengan tepat apakah perlu melakukan hedging serta memastikan apakah strategi ataupun instrumen hedging yang dipilihnya merupakan yang terbaik.

\section{TINJAUAN PUSTAKA}

\section{A. Leverage}

Rasio leverage umumnya digunakan untuk melihat kemampuan suatu industri dalam memenuhi seluruh kewajibannya. Menurut Harahap (2013), pengertian rasio leverage merupakan rasio yang mendeskripsikan korelasi antara utang perusahaan terhadap modal, rasio ini bisa melihat seberapa jauh perusahaan didanai oleh utang atau pihak luar menggunakan kemampuan perusahaan yang digambarkan oleh modal.

\section{B. Firm Size}

Menurut Ahmad (2014:7) Firm Size
atau ukuran perusahaan bisa
dipergunakan untuk mewakili ciri
keuangan perusahaan. Ukuran
perusahaan (firm size) dapat diartikan
sebagai besar kecilnya perusahaan
dapat dilihat dari nilai equity, nilai
perusahaan ataupun hasil nilai aktiva
dari suatu perusahaan. Perusahaan

dengan aset yang besar lebih banyak menerima sorotan yang berasal dari publik. Maka dari itu, perusahaan yang besar cenderung lebih banyak mengeluarkan biaya untuk menyampaikan informasi yg lebih luas sebagai upaya untuk menjaga legitimasi perusahaan. Dan menurut Seftianne (2011) firm size atau ukuran perusahaan ialah tolak ukur sebuah perusahaan yang sudah berkembang atau belum berkembang sejak perusahaan didirikan yang bisa ditinjau dari nilai total asset yang tercantum pada laporan posisi keuangan. Industri besar akan bertindak hati-hati pada pengelolaan industrinya serta lebih sering melakukan hedging. Besar dan kecilnya suatu industri dipengaruhi oleh total penjualan, total asset dan rata-rata taraf penjualan. Semakin besar ukuran perusahaan, semakin besar risiko yang dihadapi perusahaan tersebut.

\section{Financial Distress}

Financial distress artinya suatu syarat dimana perusahaan mengalami kesulitan keuangan untuk memenuhi kewajiban-kewajibannya serta berada pada posisi yang tidak aman dari ancaman kebangkrutan atau kegagalan perusahaaan tersebut. Menurut Gamayuni (2011), financial distress merupakan keadaan kesulitan keuangan atau likuiditas yang mungkin merupakan awal terjadinya kebangkrutan. financial distress terjadi saat perusahaan gagal atau tidak mampu lagi memenuhi kewajiban debitur sebab mengalami kekurangan serta ketidakcukupan dana untuk menjalankan atau melanjutkan usahanya lagi.

\section{Hedging}

Hedging adalah lindung nilai yang dilakukan perusahaan untuk menanggulangi dampak buruk dari eksposur nilai tukar. Hedging dilakukan dengan instrumen derivatif valuta asing (forward, future, option, dan swap). Penerapan kebijakan hedging pada penelitian ini akan diukur dengan 
menggunakan variabel dummy, yaitu apabila perusahaan melakukan hedging dengan instrumen derivative akan diberi skor 1, sedangkan perusahaan yang tidak melakukan hedging akan diberi skor 0 .

\section{METODE}

\section{A. Jenis Penelitian}

Penelitian yang dilakukan penulis menggunakan metode asosiatif dengan pendekatan kuantitatif. Metode asosiatif merupakan metode yang bermaksud untuk menjelaskan hubungan kausal dan pengaruh antara variabel-variabel melalui pengujian hipotesis. Menurut Asep hermawan dan Husna leila yusran (2017:5) penelitian kuantitatif adalah suatu pendekatan penelitian yang bersifat objektif mencakup pengumpulan dan analisis data kuantitatif serta menggunakan metode penguji stastistik.

B. Populasi

Populasi adalah wilayah generalisasi yang terdiri dari atas obyek atau subyek yang mempunyai kualitas dan karateristik tertentu yang diterapkan oleh peneliti untuk dipelajari dan kemudian ditarik kesimpulannya(sugiyono, 2016:80). Dengan demikian yang dimaksud populasi dalam penelitian ini adalah keseluruhan obyek yang menjadi sasaran penelitian yaitu perusahaan manufaktur yang terdaftar di Bursa Efek Indonesia .

C. Sampel

Menurut sujarweni (2014:73) “

Sampel adalah bagian dari sejumlah karateristik yang dimilik oleh populasi yang digunakan untuk penelitian".

Berdasarkan pengertian di atas, teknik sampling yang tepat Untuk menentukan sampel yang akan digunakan dalam penelitian ini adalah teknik nonprobability sampling. Dalam nonprobabilty sampling terdapat banyak cara pengambilan sampling, dalam penelitian ini peneliti menggunakan teknik pusposive sampling yaitu pengambilan sampel dari suatu populasi dengan kriteria tertentu. Adapun kriteria yang digunakan ialah sebagai berikut :

Tabel 1. Kriteria Pemilihan Sampel

\begin{tabular}{|c|l|c|}
\hline No. & \multicolumn{1}{|c|}{ Kriteria } & Jumlah \\
\hline 1. & $\begin{array}{l}\text { Perusahaan Manufaktur yang terdaftar di Bursa Efek Indonesia pada periode 2017- } \\
2020\end{array}$ & 193 \\
\hline 2. & $\begin{array}{l}\text { Perusahaan manufaktur yang tidak termasuk dalam sub-sektor makanan dan } \\
\text { minuman juga farmasi, yang terdaftar di Bursa Efek Indonesia pada periode 2017 - } \\
2020\end{array}$ & (151) \\
\hline 3. & $\begin{array}{l}\text { Perusahaan manufaktur dalam sektor makanan dan minuman, farmasi, yang tidak } \\
\text { menyediakan laporan secara berurut-urut pada periode 2017-2020 }\end{array}$ & $(16)$ \\
\hline & Total Sampel & $\mathbf{2 6}$ \\
\hline
\end{tabular}

Dengan menggunakan teknik pusposive sampling terlihat bahwa dari tabel 1 tersebut terdapat 26 perusahaan manufaktur yang terdaftar di Bursa Efek Indonesia tahun 2017-2019 layak dijadikan sebagai sampel dalam penelitian ini.

D. Teknik Analisis Data

1. Analisis Statistik Deskriptif

Analisis statistik deskriptif mempunyai tujuan untuk mengetahui gambaran umum dan deskripsi objek maupun data yang digunakan dalam penelitian ini, dengan cara melihat tabel statistik deskriptif yang menunjukkan hasil pengukuran mean, nilai minimal dan maksimal, serta standar deviasi semua variabel tersebut.

2. Regresi Logistik

Metode analisis data dalam penelitian ini menggunakan metode analisis regresi logistik. Regresi logistik dilakukan ketika peneliti ingin menguji apakah probabilitas terjadinya variabel terikat dapat 
diprediksi dengan variabel bebasnya (Ghozali, 2011).

\section{HASIL DAN PEMBAHASAN}

\section{A. Deskriptif Data}

Berikut ini akan dijelaskan descriptive statistics yaitu menjelaskan deskripsi data dari seluruh variabel yang akan dimasukkan dalam model penelitian. Data deskriptif digunakan untuk menunjukkan jumlah data yang digunakan dalam penelitian ini, serta dapat menunjukkan nilai minimum, maksimum, nilai rata-rata (mean), dan nilai standar deviasi dari masingmasing variabel penelitian. Variabel yang digunakan dalam penelitian ini terdiri dari variabel independen yaitu Debt To Equity Ratio (DER), Size (LnTA) dan financial distress, serta variabel dependen ialah hedging. Jumlah data pengamatan penelitian ini sebanyak 26 x $3=78$ data pengamatan. Dari 78 data pengamatan terdapat 24 atau sebanyak $30.77 \%$ data pengamatan yang melakukan aktivitas hedging dengan menggunakan instrumen derivatif sedangkan sebanyak 54 atau $69.23 \%$ data pengamatan tidak melakukan aktivitas hedging dengan menggunakan instrumen derivatif. Hasil olah data deskriptif dapat dilihat pada tabel 2 sebagai berikut :

Tabel 2. Hasil Analisis Descriptive statistic

\begin{tabular}{|c|c|c|c|c|c|}
\hline & $\mathrm{N}$ & Minimum & Maximum & Mean & Std. Deviation \\
\hline Leverage & 78 & -2.13 & 3.34 & .8184 & .84160 \\
Firm Size & 78 & 7.01 & 30.64 & 22.3394 & 6.58109 \\
Financial_Distress & 78 & 1.00 & 1232351509.29 & 49785053.9169 & 235176978.71986 \\
Hedging & 78 & .00 & 1.00 & .3077 & .46453 \\
Valid N (listwise) & 78 & & & & \\
\hline
\end{tabular}

Tabel 2 di atas menunjukkan bahwa jumlah observasi atau jumlah pengamatan perusahaan manufaktur sebanyak 78 data selama periode pengamatan (2017 - 2019). Berdasarkan hasil perhitungan diatas tampak bahwa Variabel leverage yang diproksikan dengan DER memiliki nilai rata-rata (Mean) sebesar 0.8184, menunjukkan bahwa rata-rata keseluruhan sampel memiliki total hutang sebesar 0.8184 dibandingkan dengan total equity-nya. Variabel DER terbesar (maximum) diperoleh PT Prasidha Aneka Niaga Tbk pada tahun 2019 sebesar 3.34, sedangkan Variabel DER terkecil (minimum) diperoleh PT FKS Food Sejahtera Tbk pada tahun 2019 sebesar 2.13. Rata-rata SIZE dalam hal ini dilihat dari total asset perusahaan sebesar 22.3394 triliun rupiah. Nilai terbesar (maximum) dari total asset diperoleh PT Kalbe Farma Tbk pada tahun 2019 sebesar 30.64 atau Rp. 20.264.726.862.584 dan nilai terkecil (minimum) diperoleh PT Tri Banyan Tirta Tbk pada tahun
2019 sebesar 7.01 atau Rp. 1.103.450.000. Rata-rata tingkat z-score yang dimiliki perusahaan yaitu sebesar 49785053.9169. Hal tersebut menunjukkan dari total sampel data perusahaan rata-rata cenderung aman dari kesulitan keuangan yang dialami. Tingkat financial distress terbesar (maximum) diperoleh PT Tri Banyan Tirta Tbk pada tahun 2017 sebesar $1,232,351,509.29$ sedangkan tingkat financial distress terkecil (minimum) diperoleh PT Bumi Teknokultura Unggul Tbk sebesar 1.00. rara-rata sampel perusahaan yang melakukan aktivitas hedging sebesar 0.3077 atau $30.77 \%$, nilai tertinggi (maximum) sebesar 1 untuk perusahaan yang melakukan aktivitas hedging dan nilai terendah (minimum) sebesar 0 untuk perusahaan yang tidak melakukan aktivitas hedging.

\section{B. Menilai Model Fit}

Pengujian ini akan menguji pengaruh dari masing-masing variabel independen yaitu leverage, Firm Size dan 
financial distress terhadap variabel dependen dalam hal ini ialah hedging. Tabel 3. Hasil Uji Model Fit

\begin{tabular}{|c|l|c|}
\hline Pengujian & \multicolumn{1}{|c|}{ Keterangan } & Nilai \\
\hline \multirow{2}{*}{$\begin{array}{c}\text { 2 Log } \\
\text { likelihood Blok } \\
\text { Number }\end{array}$} & $\begin{array}{l}-2 \text { Log likelihood } \\
\text { Blok Number 0 }\end{array}$ & 96.290 \\
\cline { 2 - 3 } & $\begin{array}{l}\text {-2 Log likelihood } \\
\text { Blok Number 1 }\end{array}$ & 83.786 \\
\hline
\end{tabular}

Dari tabel 3 dapat dilihat bahwa nilai -2 LogL pada beginning block (Block 0) adalah sebesar 96.290, setelah dimasukkan variabel independen, maka nilai -2LogL Block Number 1 mengalami penurunan menjadi 83.786. Penurunan likehood menunjukkan model regresi lebih baik atau dengan kata lain model yang dihipotesiskan fit dengan data.

C. Cox dan Snell's R Square dan Negelkerke's R Square

Nagelkerke's $R$ square merupakan modifikasi dari koefisien Cox dan Snell's $\mathrm{R}^{2}$ dengan nilai maksimumnya. Nilai Nagelkerke's $\mathrm{R}^{2}$ dapat diinterpretasikan seperti $\mathrm{R}^{2}$ pada multiple regression. Berikut hasil output spss nya :

Tabel 4. Nagelkerke's R square Model Summary

\begin{tabular}{|c|c|c|c|}
\hline \multicolumn{4}{|c|}{ Model summary } \\
\hline Step & $\begin{array}{c}-2 \text { Log } \\
\text { likelihood }\end{array}$ & $\begin{array}{l}\text { Cox \& } \\
\text { Snell R } \\
\text { Square }\end{array}$ & $\begin{array}{l}\text { Nagelkerke } \\
\text { R Square }\end{array}$ \\
\hline 1 & $83.786^{a}$ & 0.148 & 0.209 \\
\hline
\end{tabular}

Dilihat dari tabel 4 tersebut nilai

Cox $\mathcal{E}$ Snell $R$ Square sebesar 0.148 dan nilai Nagelkerke $R$ Square adalah 0,209 yang berarti bahwa variabel dependen dapat dijelaskan oleh variabel independen sebesar $20.9 \%$, sedangkan

Tabel 6. klasifikasi $2 \times 2$

Classification Table ${ }^{\mathrm{a}}$

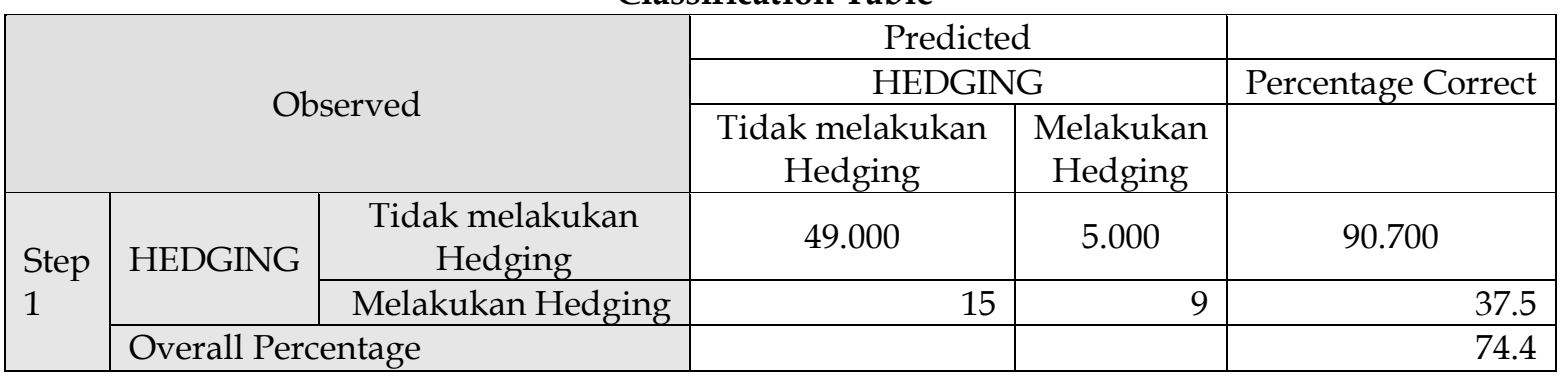

Berdasarkan tabel 6 bahwa dari 78 data penelitian yang digunakan, dapat diketahui bahwa pada kolom Predicted, prediksi perusahaan yang tidak sisanya $79.1 \%$ dapat dipengaruhi oleh variabel lain diluar penelitian ini.

D. Hosmer dan Lemeshow's Goodness of Fit test

Tabel 5. Hosmer dan Lemeshow's Goodness of

Fit test Hosmer and Lemeshow Test

\begin{tabular}{ll|r|r} 
Step & Chi-square & Df & \multicolumn{1}{c}{ Sig. } \\
\hline 1 & 13.879 & 8 & 0.085 \\
\hline
\end{tabular}

Hosmer and Lemeshow's Goodness of

Fit Test menguji hipotesis nol bahwa data empiris cocok atau sesuai dengan model (tidak ada perbedaan antara model dengan data sehingga model dapat dikatakan fit).

Tampilan outpus spss tersebut menunjukkan bahwa besarnya nilai statistik Hosmer and Lemeshow Test sebesar 13.879 dengan probabilitas signifikansi 0.085 yang nilainya lebih besar dari 0,05. Berarti tidak ada perbedaan signifikan antara hasil prediksi dengan observasi, dengan demikian dapat disimpulkan bahwa model dapat diterima.

E. Tabel Klasifikasi

Tabel klasifikasi 2 × 2 menghitung nilai estimasi yang benar (correct) dan salah (incorrect). Pada model yang sempurna, maka semua kasus akan berada pada diagonal dengan tingkat ketepatan peramalan $100 \%$. Jika model logistik mempunyai homoskedastisitas, maka prosentase yang benar (correct) akan sama untuk baris kedua (Ghozali, 2013). Berikut hasil output spss dalam memprediksi hedging : 
hedging hanya terdapat 49 perusahaan. Untuk perusahaan yang melakukan hedging terlihat pada kolom bahwa prediksi perusahaan yang melakukan hedging adalah $14(5+9)$ perusahaan. Sedangkan pada baris, hasil observasi sesungguhnya perusahaan yang melakukan hedging hanya terdapat 9 perusahaan.

Berdasarkan hasil analisis tersebut maka secara umum model yang diperoleh dari tabel klasifikasi menunjukkan bahwa tingkat overall percentage sebesar $74.4 \%$. Artinya tingkat

Tabel 7. Uji Hipotesis

Variables in the Equation

\begin{tabular}{|c|c|c|c|c|c|c|c|}
\hline & & B & S.E. & Wald & Df & Sig. & $\operatorname{Exp}(B)$ \\
\hline \multirow{4}{*}{ Step $1^{a}$} & X1 Leverage & $(0.265)$ & 0.336 & 0.620 & 1.000 & 0.431 & 0.767 \\
\hline & X2 Firm Size & -0.133 & 0.051 & 6.708 & 1 & 0.01 & 0.876 \\
\hline & $\begin{array}{l}\text { X3 Financial } \\
\text { Distress }\end{array}$ & 0 & 0 & 0.088 & 1 & 0.766 & 1 \\
\hline & Constant & 2.416 & 1.166 & 4.291 & 1 & 0.038 & 11.201 \\
\hline
\end{tabular}

Berdasarkan hasil analisis regresi logistik pada tabel 7, maka model regresi logistik adalah sebagai berikut:

$\ln \left(\frac{p i}{1-p i}\right)=Z i=2.416-0.265 \mathrm{X}_{1}-0.133 \mathrm{X}_{2}$ $+0.000 \mathrm{X}_{3}$

Dari persamaan regresi logistik tersebut menunjukkan :

a. Constant : jika seluruh variabel bebas yaitu leverage, firm size dan financial disstres bernilai 0, maka aksesibilitas hedging nilainya positif sebesar 2.416.

b. Variabel leverage memiliki koefisien yang negatif yaitu -0.265 . Hal ini menunjukkan bahwa setiap peningkatan leverage sebesar 1 , maka hedging akan menurun sebesar 0.265 dengan asumsi bahwa variabel independennya tetap.

c. Variabel firm size memiliki koefisien yang negatif yaitu -0.133. Hal ini menunjukkan bahwa setiap peningkatan leverage sebesar 1 , maka hedging akan menurun sebesar 0.133 dengan asumsi bahwa variabel independennya tetap.

d. Variabel financial distress memiliki koefisien yang positif yaitu $0.000 \mathrm{Hal}$ ketepatan model dalam memprediksi kondisi yang terjadi adalah sebesar $74.4 \%$.

\section{F. Uji Model Regresi / Uji Hipotesis}

Uji hipotesis dapat dilakukan setelah model regresi logistik mendapatkan hasil yang fit dilihat dari overall model fit, Cox and Snell $R$ Square dan Nagelkerke $R$ Square, Hosmer and Lemeshow Goodness of Fit Test, dan Classification Plot yang telah dipenuhi. Berikut merupakan tabel 7 hasil pengujian regresi binary logistic:

ini menunjukkan bahwa setiap peningkatan leverage sebesar 1, maka hedging akan meningkat sebesar 0.000 dengan asumsi bahwa variabel independennya tetap.

\section{PEMBAHASAN HASIL PENELITIAN}

1. Pengaruh Leverage (DER) terhadap keputusan hedging

Dari hasil penelitian menunjukkan bahwa leverage yang diproksikan dengan DER memiliki arah koefisien regresi yang negatif dengan nilai -0.265 dan tidak signifikan terhadap keputusan Hedging pada perusahaan manufaktur yang tedaftar di Bursa Efek Indonesia periode 2017-2019. Hal ini ditunjukkan dengan nilai signifikasi sebesar 0.431 lebih besar dari a 0.05 (5\%) itu artinya hipotesis satu $\left(\mathbf{H}_{\mathbf{a} 1}\right)$ ditolak. Dari hasil regresi dapat dijelaskan hubungan antara odds perusahaan dengan probabilitas keputusan hedging adalah apabila variabel bebas yang lain dianggap tetap, maka penurunan setiap unit variabel Leverage (DER) akan mengakibatkan probabilitas 
penggunaan hedging naik dengan faktor 0.767 .

Hasil penelitian mengenai pengaruh variabel leverage yang negatif dan tidak siginifikan terhadap keputusan hedging sama dengan penelitian Ima Mediana, Harjum Muharam (2016) dan berbeda dengan hasil penelitian Crissy Norris Sianturi, Irene Rini Demi Pangestuti (2015), Verawaty, Ade Kemala Jaya, Megawati (2019), Indra Aslikan, Siti Rokhmi (2017) yang menunjukkan bahwa leverage berpengaruh dan signifikan terhadap aktivitas hedging.

\section{Pengaruh Firm Size (LnTA) terhadap keputusan hedging}

Dari hasil penelitian menunjukkan bahwa Firm Size yang diproksikan dengan Total Asset memiliki arah koefisien regresi yang negatif dengan nilai -0.133 dan signifikan terhadap keputusan Hedging pada perusahaan manufaktur yang tedaftar di Bursa Efek Indonesia periode 2017-2019. Hal ini ditunjukkan dengan nilai signifikasi sebesar 0.010 lebih kecil dari a $0.05(5 \%)$ itu artinya hipotesis dua $\left(\mathbf{H}_{\mathbf{a} 2}\right)$ diterima. Dari hasil regresi dapat dijelaskan hubungan antara odds perusahaan dengan probabilitas menggunakan hedging adalah apabila variabel bebas yang lain dianggap tetap, maka kenaikan setiap unit variabel Firm Size akan mengakibatkan probabilitas keputusan hedging naik dengan faktor 0.876 .

Hasil penelitian mengenai pengaruh variabel Firm Size yang siginifikan terhadap keputusan hedging sama dengan penelitian yang dilakukan oleh Crissy Norris Sianturi, Irene Rini Demi Pangestuti (2015), Verawaty, Ade Kemala Jaya, Megawati (2019), dan Husna Anniyati, Hermanto, Siti Aisyah Hidayati (2020).

\section{Pengaruh Financial Distress (Altman} Z-Score) terhadap keputusan hedging

Dari hasil penelitian menunjukkan bahwa Financial Distress yang diproksikan dengan Altman Z-Score memiliki arah koefisien regresi yang positif dengan nilai 0.000 dan tidak signifikan terhadap keputusan Hedging pada perusahaan manufaktur yang tedaftar di Bursa Efek Indonesia periode 2017-2019. Hal ini ditunjukkan dengan nilai signifikasi sebesar 0.766 lebih besar dari a $0.05(5 \%)$ itu artinya hipotesis tiga $\left(\mathbf{H}_{\mathrm{a} 3}\right)$ ditolak. Dari hasil regresi dapat dijelaskan hubungan antara odds perusahaan dengan probabilitas menggunakan hedging adalah apabila variabel bebas yang lain dianggap tetap, maka kenaikan setiap unit variabel Financial Distress akan mengakibatkan probabilitas keputusan hedging naik dengan faktor 1.000.

Hasil penelitian mengenai pengaruh variabel Financial Distress yang positif dan tidak siginifikan terhadap keputusan hedging sama dengan penelitian yang dilakukan oleh Husna Anniyati, Hermanto, Siti Aisyah Hidayati (2020) dan berbeda dengan hasil penelitian Crissy Norris Sianturi, Irene Rini Demi Pangestuti (2015), Ima Mediana, Harjum Muharam (2016), Verawaty, Ade Kemala Jaya, Megawati (2019), Indra Aslikan, Siti Rokhmi (2017) yang menunjukkan bahwa financial distress berpengaruh dan signifikan terhadap aktivitas hedging.

\section{PENUTUP}

\section{Kesimpulan}

a. Dari hasil penelitian menunjukkan bahwa leverage yang diproksikan dengan DER memiliki arah koefisien regresi yang negatif dan tidak signifikan terhadap keputusan Hedging pada perusahaan manufaktur yang tedaftar di Bursa Efek Indonesia periode 2017-2019.

b. Dari hasil penelitian menunjukkan bahwa Firm Size yang diproksikan dengan Total Asset memiliki arah koefisien regresi yang negatif dan signifikan terhadap keputusan Hedging pada perusahaan manufaktur yang tedaftar di Bursa 
Efek Indonesia periode 2017-2019.

c. Dari hasil penelitian menunjukkan bahwa Financial Distress yang diproksikan dengan Altman Z-Score memiliki arah koefisien regresi yang positif dan tidak signifikan terhadap keputusan Hedging pada perusahaan manufaktur yang tedaftar di Bursa Efek Indonesia periode 2017-2019.

\section{Saran}

Bagi Peneliti selanjutnya disarankan untuk menambah variabel independent yang lain karena dalam penelitian ini variabel independent $(X)$ terbilang sedikit yaitu leverage, firm size dan financial distress yang hanya menjelaskan variabel hedging sebesar $20.9 \%$, sedangkan sisanya $79.1 \%$ dapat dipengaruhi oleh variabel lain diluar penelitian ini.

Penelitian selanjutnya juga diharapkan menggunakan sampel yang lebih banyak atau sektor industri lainnya serta memperpanjang periode penelitian sehingga lebih mampu menjelaskan faktor-faktor yang mempengaruhi keputusan hedging perusahaan.

\section{DAFTAR PUSTAKA}

Ahmad, Gatot Nazir dan Vina Kusuma Wardani. 2014. The Effect of Fundamental Factor to Dividend Policy: Evidence In Indonesia Stock Exchange. International Journal of Business and Commerce. Vol. 4. No. 02 : October 2014 (14-25).

Crissy Norris Sianturi, I. R. (2015). Pengaruh Liquidity, Firm Size, Growth Opportunity, Financial Distress, Leverage, dan Managerial Ownership terhadap Aktivitas Hedging dengan Instrumen Derivatif (Studi Kasus pada Perusahaan Non Finansial yang Terdaftar di BEI Periode 2010-2014). Diponegoro Journal of Management, 113.

Djohanputro, B. (2013). Manajemen Risiko Korporat Terintegrasi, Panduan
Penerapan dan Pengembangan. Jakarta: PPM.

Ekananda, M. (2014). Ekonomi Internasional. Jakarta: Erlangga.

Fahmi, I. (2016). Manajemen Risiko, Edisi Revisi, Cetakkan keenam. Bandung: Alfabeta.

Gamayuni, R. R. (2011). Analisis Ketepatan Model Altman Sebagai Alat Untuk Memprediksi Kebangkrutan. Jurnal Akuntansi dan Keuangan, vol. 16 No.2.

Ghozali, Imam. (2011). “Aplikasi Analisis Multivariate Dengan Program SPSS". Semarang: Badan Penerbit Universitas Diponegoro.

Hady, H. (2012). Manajemen Keuangan Internasional. Jakarta: Mitra Wacana Media.

Hanafi, M. M. (2016). Manajemen Risiko. Yogyakarta: UPP STIM YKPN.

Harahap, Sofyan Syafri, 2013, Analisis Kritis Atas Laporan Keuangan, Cetakan Kesebelas, Penerbit Rajawali Pers, Jakarta

Husna A., Hermanto dan Siti Aisyah H. (2020). Pengaruh Firm size, Financial Distress, Debt Level dan Managerial Ownership terhadap Keputusan Hedging pada Perusahaan Manufaktur yang terdaftar di Bursa Efek Indonesia. Jurnal Magister Manajemen, Universitas Mataram. Volume 9 No.1 2020.

Lutfi, A. M., et al. (2021). Pengaruh Capital Adequacy Ratio Dan Bopo Ratio Terhadap Return On Asset Pada Pt. Bank Muamalat Indonesia, Tbk Periode 2010-2019. Jurnal Ekonomi Efektif, 3(3), 420-428.

Norken, I. N. (2015). Pengantar Analisis dan Manajemen Risiko pada Proyek Konstruksi. Denpasar: Universitas Udayana Press.

Syaryadi, Fikri. (2012). Pengaruh Rasio Likuiditas Terhadap Financial Distress Perusahaan Industry Tekstil dan Garmen yang Terdaftar di Bursa Efek Indonesia. Jakarta: Digilib.polsri.ac.id. 